\title{
Towards the development of controllable and reversible 'on-off' luminescence switching in soft-matter; synthesis and spectroscopic investigation of 1,8-naphthalimide-based PET (photoinduced electron transfer) chemosensors for $\mathrm{pH}$ in water-permeable hydrogels
}

\author{
Thorfinnur Gunnlaugsson, ${ }^{a^{*}}$ Colin P. McCoy, ${ }^{\text {* }}$ Ryan J. Morrow, ${ }^{\mathbf{b}}$ Caroline Phelan, ${ }^{\mathrm{a}}$ \\ and Floriana Stomeo ${ }^{\mathrm{a}}$ \\ ${ }^{a}$ Department of Chemistry, Centre for Synthesis and Chemical Biology, Trinity College Dublin, \\ Dublin 2, Ireland and \\ ${ }^{b}$ School of Pharmacy, Queen's University Belfast, 97 Lisburn Road, Belfast BT9 7BL, UK \\ E-mail:gunnlaut@tcd.ie
}

Dedicated to Professor Michael Anthony McKervey on his $65^{\text {th }}$ birthday

(received 01 Mar 03; accepted 27 May 03; published on the web 30 May 03)

\begin{abstract}
The synthesis of the pH PET sensors $\mathbf{1}$ and $\mathbf{2}$ is described. These molecules display 'on-off' switching in their fluorescence as a function of $\mathrm{pH}$ in aqueous solution. From the luminescent changes $\mathrm{pK}_{\mathrm{a}}$ values of $8.4( \pm 0.1)$ and $6.3( \pm 0.1)$ were determined respectively. These compounds were incorporated into poly[methylmethacrylate-co-2-(hydroxyethylmethacrylate)]-based hydrogels and the luminescent properties of the resulting polymeric films were investigated using confocal laser-scanning microscopy. Both sensors showed substantial luminescent switching in the soft-matter, where the emission was 'switched off' after treating the hydrogels with alkaline solution and 'switched on' under acidic conditions.
\end{abstract}

Keywords: Fluorescent sensor, switches, $\mathrm{pH}$, hydrogels

\section{Introduction}

There is currently great interest within the field of supramolecular chemistry in developing miniaturized molecular devices that mimic or mirror the action of macroscopic devices such as switches, motors and other machinery. ${ }^{1}$ Supramolecular devices that show large changes in their so called 'off' and 'on' states, where their 'states' refer to their luminescence, magnetic, or electronic properties, are of particular interest as these can be modulated, or tuned, by employing external sources, or 'inputs', such as ions, molecules, light, etc. ${ }^{2,3}$ A part of this rapidly emerging 
field is the developments of simple chemical sensors and switches. ${ }^{4}$ In recent times, the development of luminescent based chemosensors for medical application has become highly desirable, in particular for use in clinical diagnosis, for monitoring essential electrolytes and small molecules (such as oxygen, sugars, etc.) in so-called 'whole-blood' measurements. 5

We are active in this field and have previously developed fluorescent switches and sensors where the fluorescence is modulated or switched 'on' or 'off' as a function of the analyte. ${ }^{6}$ These types of sensor are based on the use of the 'fluorophore-spacer-receptor' model developed by de Silva at Queen's University Belfast. ${ }^{7}$ In this design the excited state of the fluorophore can be quenched by intermolecular electron transfer from the receptor to the fluorophore (or vice versa) prior to the recognition. Upon recognition of species such as cations, the oxidation potential of the receptor is increased and this causes the electron transfer to be 'switched off' and in turn the emission to be 'switched on'. anions (such as acetate and phosphate) and bis-anions (such as pyrophosphate, lactate etc.) ${ }^{9}$ In these modified systems the emission is 'switched on' prior to the anion recognition, but upon recognition the reduction potential of the receptor is increased giving rise to enhanced quenching and hence the emission is 'switched off'.

Recently we have further extended this area of research by developing both colorimetic ${ }^{10}$ and also 'delayed lanthanide luminescence' sensors, by employing Eu(III) and Tb(III) which emit at long wavelengths with characteristic line-like emissions. These sensors benefit from large signal to noise ratio and a high signal quality. ${ }^{11}$ Such long-lived excited states (in the ms range), are highly desirable for in vivo sensing since they overcome short-lived ( ns) background emission or autofluorescence and light scattering from the active biological environment.

Another way of overcoming these features is to have fluorophores that absorb and emit at long wavelengths. ${ }^{12}$ Specifically, 4- or 3-amino-1,8-naphthalimides are of particular interest in this respect. ${ }^{5,12,13}$ They absorb around $450 \mathrm{~nm}$ and emit in the green, with $\lambda_{\max } \sim 550 \mathrm{~nm}$ and a high fluorescence quantum yield. Moreover, they are easily synthesized in bulk quantities as well as being well suited for incorporation into polymeric matrixes and onto solid-surfaces. These properties are essential when employing such devices in real-time and on-line analysis. However, such immobilization often decreases the efficiency of the sensors, in particular as they are often placed into organic phases or lipophilic membranes that effect the uptake of the aqueous based analyte, the response time and the photophysical properties of the solid state device are also affected. ${ }^{5}$

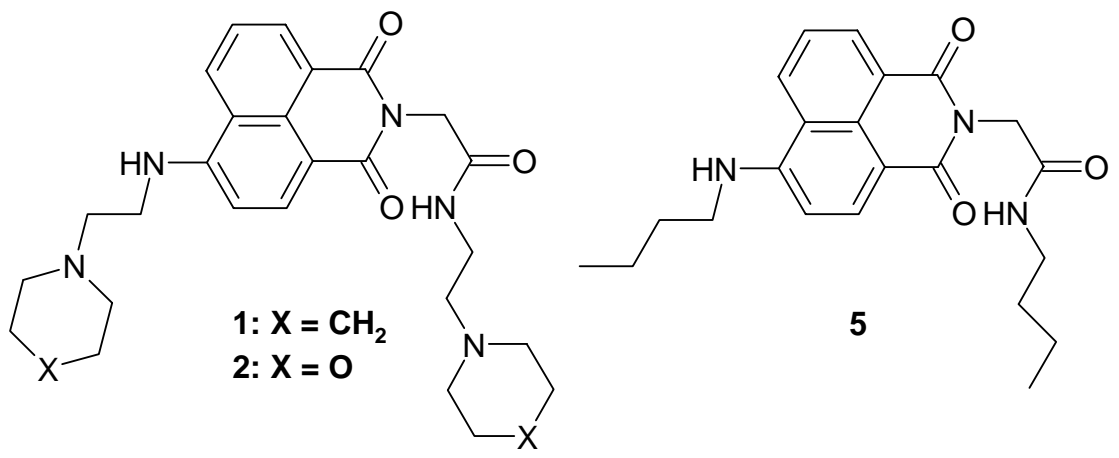


With this in mind we set out to develop novel fluorescent chemosensors based upon the amino-1,8-napthalimide structure and incorporate these into water-permeable hydrogels. Such hydrogels are easily handled and, when the composition is chosen judiciously, do not require that the sensor be covalently bonded to the polymeric matrix. ${ }^{5,14,15}$ Compounds $\mathbf{1}$ and $\mathbf{2}$ are examples of our general design. In this paper we give account of our recent results on the synthesis of, as well as the solution and the soft-matter luminescent properties, of $\mathbf{1}$ and $\mathbf{2}$ as a function of $\mathrm{pH}$. $^{\S}$

\section{Results and Discussion}

\section{Design and synthesis of 1 and 2}

The two chemosensors were designed for determining $\mathrm{pH}$ changes in the physiological $\mathrm{pH}$ range. As previously mentioned they are based on the 'fluorophore-spacer-receptor' model developed by de Silva, where the 4-amino-1,8-naphthalimide moiety is the fluorophore and the piperidine and the morpholine amines are the proton acceptors. The ethylene spacer covalently separates the two units. In these particular cases, it was predicted that an electron transfer from the amine to the excited state of the fluorophore would quench fluorescence emission of the naphthalimide unit. This would represent the 'off-state' as previously discussed. ${ }^{16}$ In retrospect, the protonation of these amino moieties would increase the oxidation potential of the receptor, and as such, thermodynamically disallow the electron transfer. ${ }^{16}$ Consequently the emission would be 'switched on'. We chose piperidine and morpholine based amino derivatives to carry out this 'switching', but these two moieties have $\mathrm{pKa}$ 's that overlap the physiological $\mathrm{pH}$ range.

As can be seen from these molecules, two amino moieties ('upper' and 'lower') were incorporated into the sensors. However, as demonstrated experimentally by de Silva et al. ${ }^{16}$ only the receptor that is directly attached to the 4-amino moiety (the 'lower' moiety) is capable of quenching the excited state of $\mathbf{1}$ and 2 . This is due to the fact that molecules like $\mathbf{1}$ and $\mathbf{2}$, have high exited state dipole moments that arise from their Internal Charge Transfer (ICT) excited state nature. In the case of $\mathbf{1}$ and $\mathbf{2}$ the amino moiety is acting as an electron donor, whereas the imide functions as an electron acceptor. Consequently, a push-pull mechanism is in operation, and due to charge repulsion, disallows the 'upper' amino to transfer an electron to the naphthalimide excited state. However, we predicted that the upper amine would substantially increase the water solubility of these molecules making them more acceptable to incorporation into hydrogels. This was indeed found to be the case as is discussed later.

The synthesis of $\mathbf{1}$ and $\mathbf{2}$ was achieved in two steps as shown in Scheme 1. The ester $\mathbf{4}$ was made in 77\% yield by reacting the 4-chloro-1,9-naphthalic anhydride with glycine methyl ester in refluxing anhydrous toluene in the presence of triethyl amine. The desired product was isolated after treating it with aqueous acid, and recrystallization from methanol. The two chemosensors 1 and 2 were subsequently formed by reacting 4 in large excess of either 4-(2aminoethyl)-piperidine or 4 -(2-aminoethyl)-morpholine at $80^{\circ} \mathrm{C}$ for 12 hours. The resulting solutions were then cooled to room temperature before pouring them onto an ice water solution 
with vigorous stirring. The two products were then isolated by filtration and washed several times with $1 \mathrm{M} \mathrm{HCl}$ solution, affording the two products in 74 and $80 \%$ yield respectively. No further purification was necessary.<smiles>O=C1OC(=O)c2ccc(Cl)c3cccc1c23</smiles>

3

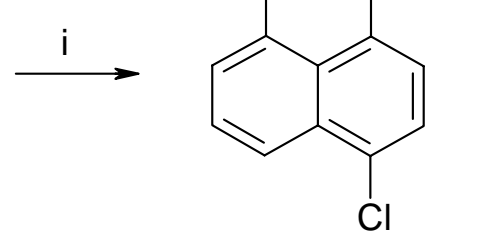

4

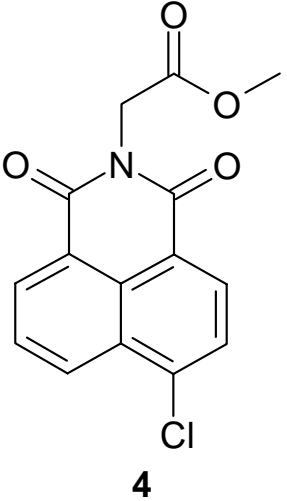

LOWER

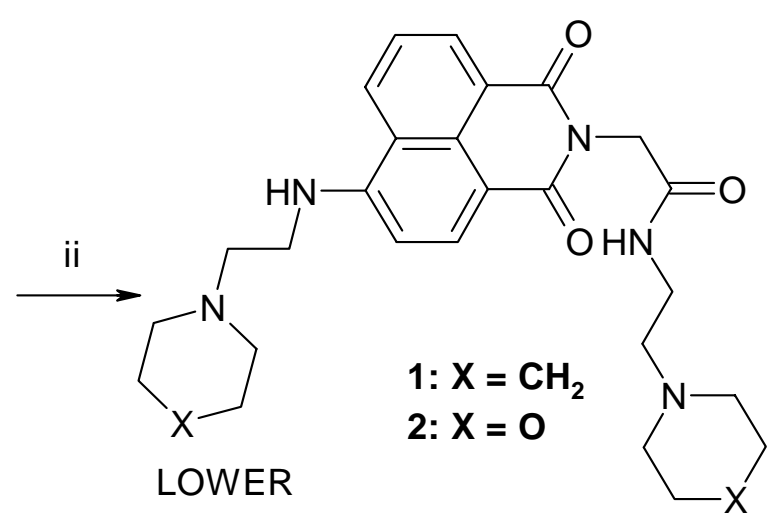

UPPER

Scheme 1. i) Glycine methyl ester $\mathrm{HCl}$, toluene, triethyl amine, reflux 12 hours. ii) Neat amine, $80^{\circ} \mathrm{C} 12$ hours.

The structures and purities of the desired products were confirmed by conventional techniques. For instance, in the ${ }^{1} \mathrm{H}$ NMR $\left(400 \mathrm{MHz}, \mathrm{CDCl}_{3}\right)$ spectra a resonance at $6.56 \mathrm{ppm}$ was observed. This is characteristic for the proton in position 3 of the naphthalimide ring. Furthermore, the protons for the two piperidine and the two morpholine moieties appear overlapped, but integrate to the correct number of protons for bi-substituted molecules. During the synthesis of $\mathbf{1}$ and $\mathbf{2}$, no traces of the mono-substituted product were detected. Furthermore, the electro-spray mass spectrum contained the $\mathrm{M}^{+}$peaks at 492.3 and 495.8 and the $\mathrm{M}+\mathrm{Na}^{+}$(due to complexation of $\mathrm{Na}+$ form solvent during ionization) for $\mathbf{1}$ and $\mathbf{2}$ respectively, as well as showing some $\mathrm{M}^{+} / 2$ and $\mathrm{M}+\mathrm{Na}^{+} / 2$ peaks, but no peaks attributed to the mono-substituted products.

\section{Incorporation of 1 and 2 into hydrogels}

In order to study the behaviour of $\mathbf{1}$ and $\mathbf{2}$ in a hydrogel matrix, $\mathbf{1}$ and $\mathbf{2}$ were effectively immobilized in a hydrogel comprising poly[methylmethacrylate-co-2(hydroxyethylmethacrylate)] in a monomer ratio of 3:1 methylmethacrylate (MMA) to 2(hydroxyethylmethacrylate) (HEMA) by weight, crosslinked with $1 \%$ by weight ethyleneglycol dimethacrylate and swollen to equilibrium in water. Hydrogels are, by definition, crosslinked polymers capable of taking up a significant proportion of their own weight of water while remaining insoluble in water. ${ }^{17}$

Amongst the most widely studied hydrogels are those based on poly(2(hydroxyethylmethacrylate)) (pHEMA). ${ }^{18}$ pHEMA hydrogels swell markedly in water and swollen materials can comprise up to $70 \%$ water, depending on the quantity of crosslinker employed. ${ }^{18,19}$ Such 
hydrogels were found to be unsatisfactory for the current study as the permeability of the hydrogel was found to be such that immobilization of $\mathbf{1}$ and $\mathbf{2}$ was not permanent. To reduce the permeability, MMA was copolymerized with HEMA to give copolymers comprising a MMA/HEMA ratio of 3:1 (w/w). Using MMA as a comonomer contributes hydrophobic character to the resulting copolymer as homopolymeric pMMA takes up significantly less water than pHEMA. In order to achieve a homogeneous dispersion of $\mathbf{1}$ or $\mathbf{2}$ in the hydrogel, the appropriate sensor was dissolved in the monomer mixture prior to polymerization.

The mean equilibrium water content of the hydrogels studied was determined by measurement of loss in weight of three replicates of a sample following dehydration at $60^{\circ} \mathrm{C}$ for three days to constant weight. Hydrogels containing either $0.05 \%$ by weight 1 or 2 were found to comprise $10.1 \pm 0.6 \%$ by weight water. The equilibrium water content of the hydrogels was found to be $\mathrm{pH}$ independent, which is expected as the hydrogel contains no functional groups ionisable in the $\mathrm{pH}$ range studied. The immobilization of $\mathbf{1}$ or $\mathbf{2}$ was verified by allowing hydrogel segments to soak for 1 month in deionized water. This water was found to contain no trace of sensor as determined by UV-visible and fluorescence spectroscopies.

\section{Ground and excited state investigation of 1 and 2 in solution}

The photophysical properties of 1 and 2 were investigated in water, in the presence of $0.1 \mathrm{M}$ tetramethylammonium chloride (TMACl) to maintain constant ionic strength, prior to the incorporation into the hydrogels. Both compounds are highly coloured. When the UV-Visible spectra of 1 and 2 were recorded in alkaline solution at $\mathrm{pH} \mathrm{12,} \mathrm{a} \mathrm{broad} \mathrm{absorption} \mathrm{was} \mathrm{observed}$ between 350 and $530 \mathrm{~nm}$ due to the ICT state (Figure 1), with $\lambda_{\text {abs }}$ maximum at $450 \mathrm{~nm}$. Upon acidification the band was blue shifted with small reductions in its maximum intensity at $\mathrm{pH}$ 6.42. However, upon further acidification the $\lambda_{\text {abs }}$ became further blue shifted with small intensity enhancements. These changes can however, be considered to be only minor in comparison to the changes in the fluorescence spectra (see later). The reason for the blue shift is twofold. First, the protonation of the 'lower' tertiary amine will exert some weak charge repulsion on the 4-amino moiety of the fluorophores. However, the major reason is that in very acidic conditions the push-pull character of the ICT state is partially reduced due to the protonation of the 4-amino moiety itself (the $\mathrm{pKa}$ of this moiety is very low).

The fluorescence emission spectra of $\mathbf{1}$ and $\mathbf{2}$ were also recorded in water in the presence of $0.1 \mathrm{M}$ TMACl. In alkaline solution only a week emission was observed between 480 and $640 \mathrm{~nm}$ (Figure 2), with $\lambda_{\max }$ at $c a .550 \mathrm{~nm}$. However, upon acidification the emission was gradually increased as demonstrated in Figure 2 for 2. Similar results were found for 1. After careful titration from $\mathrm{pH} 12$ to 2.5 , the emission maximal had shifted to $c a .535 \mathrm{~nm}$, and the emission intensity had enhanced by over an order of magnitude. These changes are of such magnitude that they can be considered as representing two different 'states', where the fluorescence emission is 'switched off' in alkaline solution and 'switched on' in acidic solution. These changes are due to the protonation of the 'lower' amino moieties of the piperidine and the morpholine moieties. In 
alkaline solution these moieties are engaged in PET quenching of the naphthalimide excited state, and upon protonation of these amines this quenching process in substantially removed. As can be seen from Figure 2, some emission is observed in the alkaline solution. As the electron transfer is distance dependent (a function of $1 / \mathrm{r}^{6}$ ), for $\mathbf{1}$ and $\mathbf{2}$ the ethylene spacer gives rise to some deactivation of the excited state, even in alkaline solution, where it is in competition with PET. ${ }^{20}$ However, it has recently been reported that the ethylene spacer shows greater biological resistance to degradation then a methylene spacer (which is commonly used), ${ }^{7,8}$ which is important in the present context as these sensors are developed with the aim of continuous monitoring of $\mathrm{pH}$ in blood. ${ }^{5}$

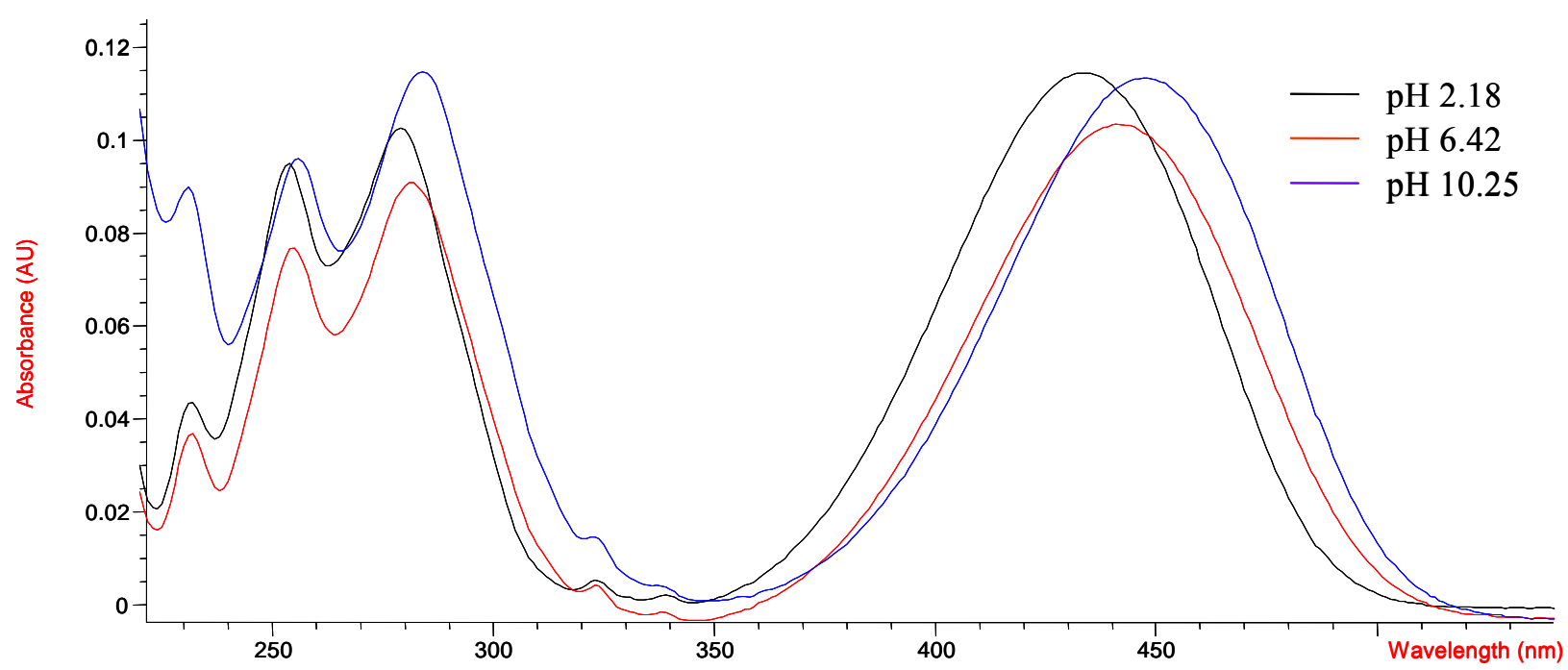

Figure 1. The UV-Visible spectra of 2 in water at three different pHs.

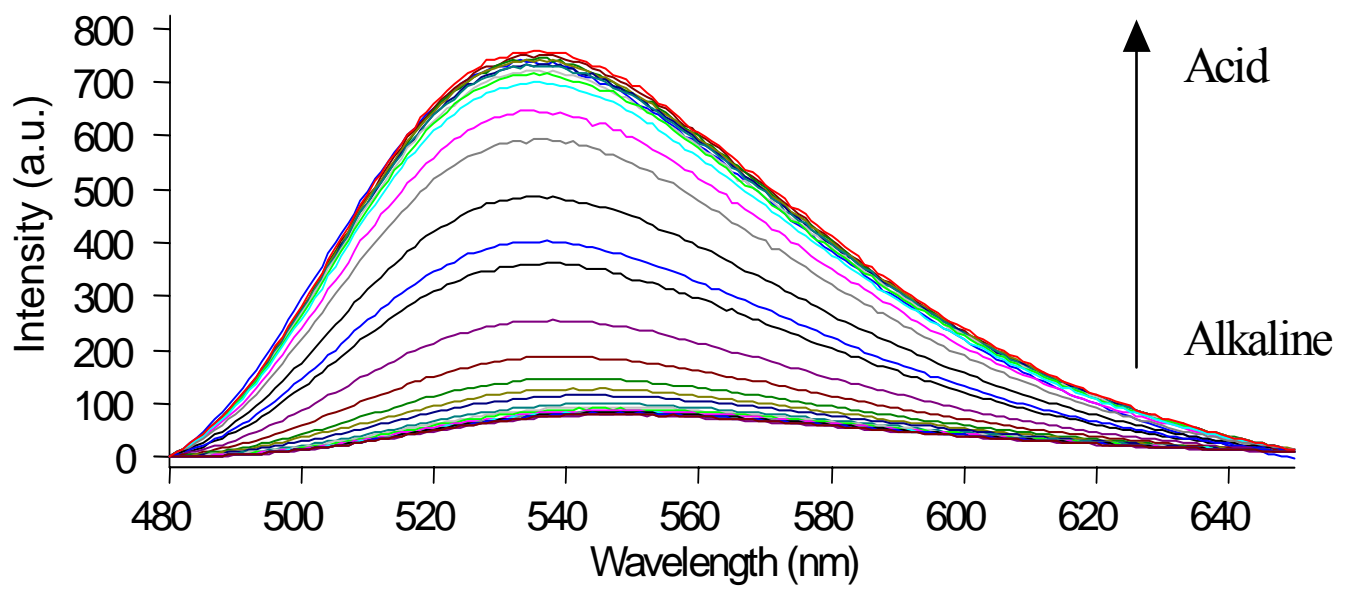

Figure 2. The changes in the fluorescence emission spectra of 2 as a function of $\mathrm{pH}$ in water. The $\mathrm{pH}$ range was from 12-2.5. 
In contrast to the above results, compound 5, which lacks the amino receptor, did not show any changes in emission properties as a function of $\mathrm{pH}$ except at very low $\mathrm{pH}$ where the 4-amino moiety was protonated. Compounds $\mathbf{1}$ and $\mathbf{2}$ are thus highly efficient 'off-on' switches for $\mathrm{pH}$. This switching process was also found to be reversible. From the changes in the fluorescence emission spectra as a function of $\mathrm{pH}$, the $\mathrm{pKa}$ 's of the two sensors can be determined. Figure 3, shows these changes when measured at $536 \mathrm{~nm}$. From these changes the emission is 'switched off-on' between ca. pH 7.5 and 9.5 for 1 and ca. 5.5 and 7.5 for 2, which is an indication of 1:1 binding and simple equilibrium. From these changes a pKa values of $8.4( \pm 0.1)$ and $6.3( \pm 0.1)$ were determined. These results are consistent with compounds of similar nature that were developed by de Silva et al. ${ }^{21}$ These $\mathrm{pK}_{\mathrm{a}}$ values also indicate that these sensors, and in particularly 2, would be well suited to monitor changes in the upper and the lower parts of the physiological $\mathrm{pH}$ range respectively.
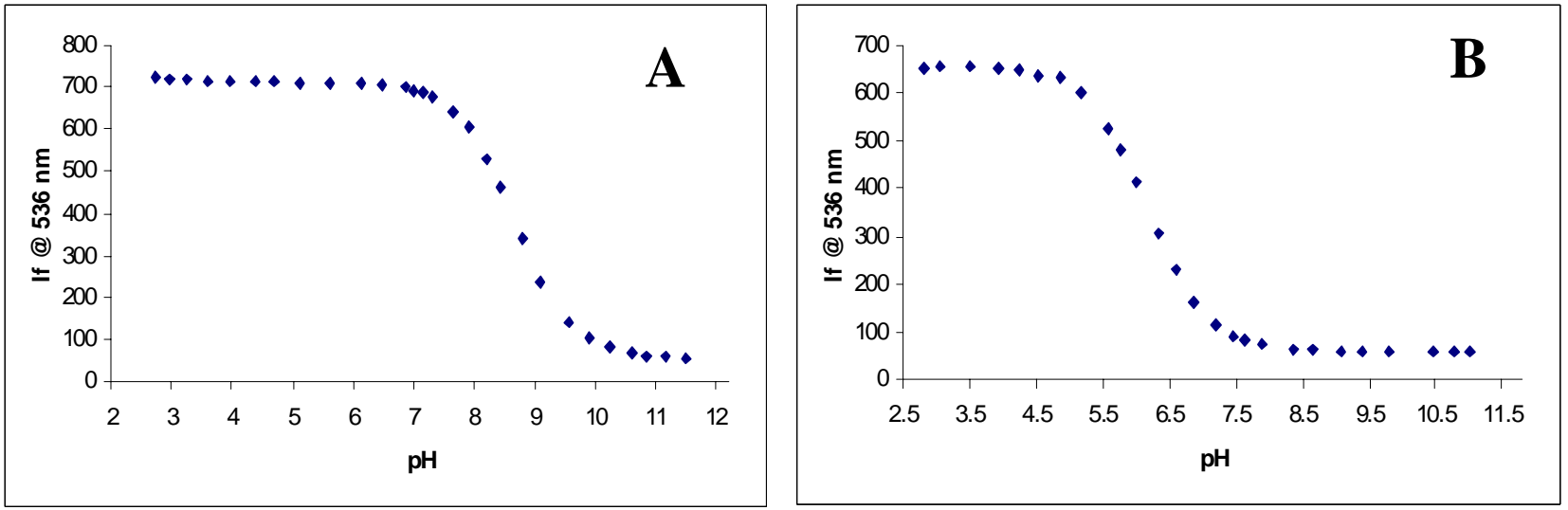

Figure 3. The changes in the fluorescence emission spectra of $\mathbf{1}$ (A) and 2 (B) at $536 \mathrm{~nm}$ as a function of $\mathrm{pH}$.

\section{Investigation of 1 and 2 after incorporation into hydrogels}

As stated above the incorporation of these sensors into hydrogels was straightforward, as our design does not require the covalent incorporation into polymeric matrixes such as aminocellulose prior to the hydrogel formation.

As the hydrogel material used for immobilization of the sensors contains water, it was expected that the photophysical behaviour of $\mathbf{1}$ and $\mathbf{2}$ would be largely similar to that in solution. In order to characterize this behaviour, in situ fluorescence behaviour and distribution of $\mathbf{1}$ and $\mathbf{2}$ in the hydrogel matrices was examined using confocal laser-scanning microscopy (CLSM). CLSM allows direct, non-invasive measurement of fluorescence from the surface of a sample following excitation from an appropriate laser source. ${ }^{22}$ To build up a single image, data is collected pixel by pixel with the laser rastering over the sample, with measurement of overall fluorescence intensity within a defined wavelength range being translated into a false colour for each pixel which correlates with that intensity. ${ }^{23}$ Using this technique it is therefore possible to 
obtain a spectrophotometric measurement of fluorescence emission from any defined area within a collected series of images. This allowed us to characterize both the distribution of the sensors within the hydrogel matrices and the fluorescence emission characteristics of the sensors on a macro (from square micron up to square millimetre) scale. Excitation was achieved using the $458 \mathrm{~nm}$ line from a Ar/ArKr laser and monochromated $\mathrm{xy} \lambda$ data was collected as a series of scans with data being collected every $2.5 \mathrm{~nm}$ with a bandwidth of $5 \mathrm{~nm}$ over the range $465-750 \mathrm{~nm}$. A typical image showing emission integrated over the range 465-750nm is shown in Figure 4.

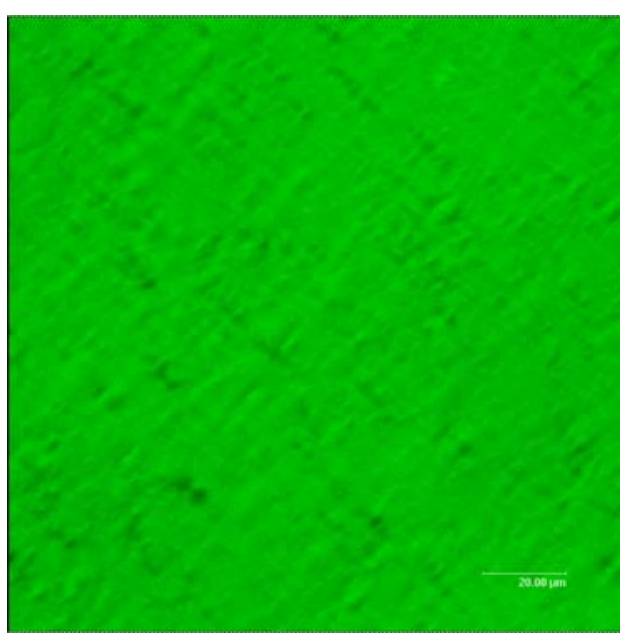

Figure 4. CLSM image of a typical section of hydrogel incorporating $0.05 \% \mathrm{w} / \mathrm{w} 2$, showing the homogeneity of the sensor within the hydrogel. This image was recorded at $\mathrm{pH} 2.5$.

The $\mathrm{xy} \lambda$ data collected allowed fluorescence emission spectra from the surface of the bulk material in both acidic and basic media to be obtained. Figure 5 shows the fluorescence emission spectra obtained from a hydrogel containing 2 at $\mathrm{pH}$ values of 2.5 and 11.5.

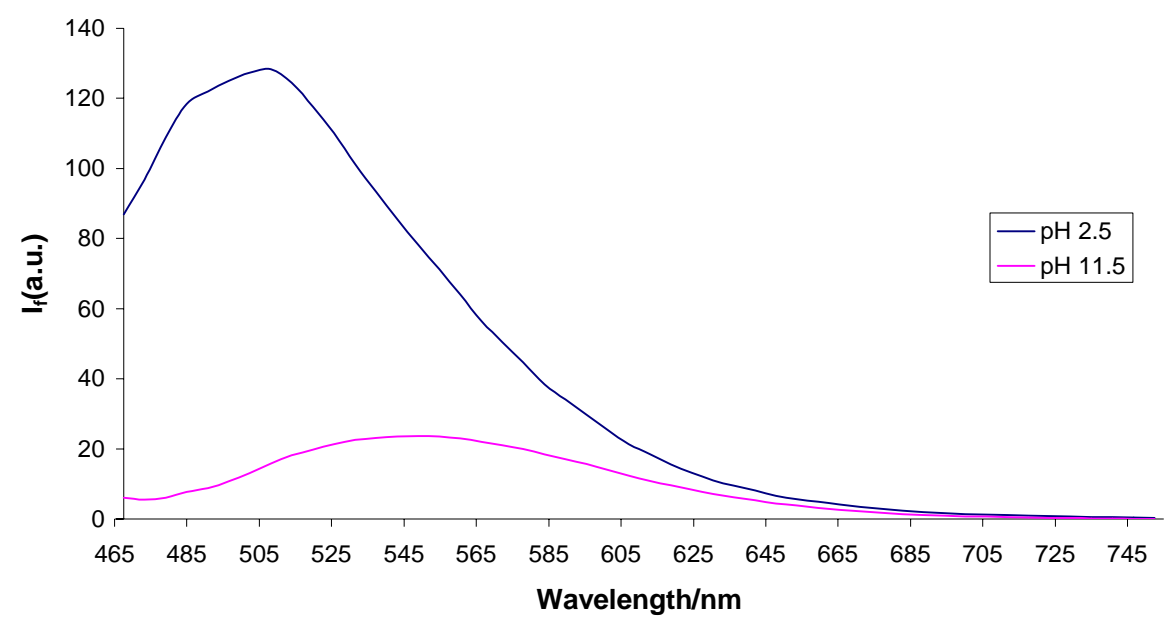

Figure 5. Fluorescence emission spectra obtained from a hydrogel containing $0.05 \% \mathrm{w} / \mathrm{w} 2$ at $\mathrm{pH}$ values of 2.5 and 11.5 . 
As with solution measurements, the fluorescence behaviour of immobilized sensors was found to be strongly $\mathrm{pH}$ dependent, with a decrease in maximum intensity of emission of approximately an order of magnitude for a hydrogel at $\mathrm{pH} 11.5$ compared to at $\mathrm{pH} 2.5$. The emission maximum at $\mathrm{pH} 11.5$ occurs at $550 \mathrm{mn}$ and at $\mathrm{pH} 2.5$ at $510 \mathrm{~nm}$. This is consistent with the destabilization of the ICT excited state due to the proximity of the protonated amine to the partially positively charged end of the molecule at $\mathrm{pH} 2.5$ as discussed for solution measurements. However, while the maximum at $\mathrm{pH} 11.5$ occurs at almost the same wavelength as in solution $(550 \mathrm{~nm})$, the maximum at $\mathrm{pH} 2.5$ is further bathochromically shifted to $510 \mathrm{~nm}$ compared to that observed in solution $(532 \mathrm{~nm})$. This difference is attributable to the intermolecular forces between the sensors and the hydrophobic polymer chains, which further destabilize the polar excited state. We are currently carrying out further experiments on these compounds in hydrogels to quantify the effect of the adsorption of $\mathbf{1}$ and $\mathbf{2}$ on pHEMA chains. This work will be the subject of future publications.

\section{Conclusions}

In this paper we have given a comprehensive account of the design of two new pH PET sensors for monitoring $\mathrm{pH}$ changes in the physiological $\mathrm{pH}$-range. The determined $\mathrm{pK}_{\mathrm{a}}$ values for the two chemosensors $\mathbf{1}$ and $\mathbf{2}$ indicated that they would be able to monitor the necessary $\mathrm{pH}$ range. We incorporated these sensors into hydogels without having to covalently bind them to a resin or a polymeric support prior to incorporation. The luminescence properties of the resulting films were investigated using confocal laser-scanning microscopy. For both the emission was switched 'off' or 'on' as a function of $\mathrm{pH}$, mirroring the behaviour in aqueous solution. We are currently investigating these features in much greater detail including developing films of different composition and thickness as well as incorporating chemosensors for other ions and molecules into these hydrogels.

\section{Experimental Section}

General Procedures. Melting points were determined using Electrothermal 1A9000 melting point apparatus. Infrared spectra were recorded on a Mattson Genesis II FTIR spectrophotometer equipped with a Gateway 2000 4DX2-66 workstation. Solid samples were dispersed in $\mathrm{KBr}$ and recorded as clear pressed discs. ${ }^{1} \mathrm{H}$ NMR spectra were recorded at $400 \mathrm{MHz}$ using a Bruker Spectrospin DPX-400 instrument. ${ }^{13} \mathrm{C}$ NMR were recorded at $100 \mathrm{MHz}$ using a Bruker Spectrospin DPX-400 instrument (both are referred to chloroform). Mass spectra were determined by detection using Electrospray on a Micromass LCT spectrometer, using a Waters HPLC. The whole system was controlled by MassLynx 3.5 on a Compaq Deskpro workstation. UV-Vis spectra were recorded on Shimadzu UV-2401 PC UV-Vis spectrometer (See Experimental Section). 
Solution fluorescence emission spectra were recorded using Varian Cary Eclipse Fluorescence Spectrophotometer. Typically a solution of the sensor was made up with optical density of $0.2-0.25$ in 50:50 MeOH: $\mathrm{H}_{2} \mathrm{O}$ solvent systems containing the ionic strength. $\mathrm{pH}$ titrations were carried out by adjusting the $\mathrm{pH}$ of the above solution $(10-20 \mathrm{ml})$ to high alkaline value (TBAOH or $\mathrm{KOH}$ ) and aliquots of acid ( $\mathrm{HCl}$ or TFA) were added. Determination of $\mathrm{pKa}$ and $\mathrm{pM}$ values was according to published proceadure. ${ }^{17}$

\section{Hydrogel preparation}

Crosslinked poly[methylmethacrylate-co-2-(hydroxyethylmethacrylate)] hydrogels were prepared by stirring a mixture of methylmethacrylate $(7.35 \mathrm{~g}), 2$-(hydroxyethylmethacrylate) $(2.45 \mathrm{~g})$, ethyleneglycol dimethacrylate $(0.1 \mathrm{~g})$, azo-bis-isobutyronitrile $(0.1 \mathrm{~g})$ and either sensor 1 or $2(0.005 \mathrm{~g})$ until solution was complete, followed by injection of the monomer mixture into a $1 \mathrm{~mm}$ mould with release liner. The mould was heated at $90^{\circ} \mathrm{C}$ for 6 hours and the resulting material washed thoroughly with deionised water and soaked in deionised water for 3 days.

\section{Synthesis}

$\mathbf{N}$-(1-Methoxycarbonyl-methyl)-4-chloro-1,8-naphthalimide (4). Glycine methyl ester hydro chloride (1.6 g, 12.7 mmol, 1.5 eq.), 4-chloro-1,8-naphthalic anhydride (2 g, 8.6 mmol, 1 eq.) and triethylamine $(1.3 \mathrm{~g}, 1.8 \mathrm{ml}, 12.7 \mathrm{mmol}, 1.5 \mathrm{eq}$.$) were refluxed in toluene (100 \mathrm{ml})$. After filtration through celite the mixture was reduced to dryness under reduced pressure. The resulting residue was dissolved in DCM and washed twice with $1.0 \mathrm{M} \mathrm{HCl}$, once with water, dried over $\mathrm{MgSO}_{4}$ and the solvent removed under reduced pressure, to give the desired product as a brown crystalline solid after recrystallisation from $\mathrm{MeOH}(2.0 \mathrm{~g})$, in $77.0 \%$ yield. m. p. $158-159^{\circ} \mathrm{C}$; $\mathrm{m} / \mathrm{z}$ found $304.0377\left([\mathrm{M}+\mathrm{H}]^{+} \mathrm{C}_{15} \mathrm{H}_{11} \mathrm{NO}_{4} \mathrm{Cl}\right.$ requires 304.0371$) ; \delta_{\mathrm{H}}\left(400 \mathrm{MHz}, \mathrm{CDCl}_{3}\right), 8.72$ $(1 \mathrm{H}, \mathrm{d}, J=7.5 \mathrm{~Hz}, \mathrm{Ar}-\mathrm{H} 5), 8.58(1 \mathrm{H}, \mathrm{d}, J=8.0 \mathrm{~Hz}, \mathrm{Ar}-\mathrm{H} 7), 8.51(1 \mathrm{H}, \mathrm{d}, J=7.5 \mathrm{~Hz}, \mathrm{Ar}-\mathrm{H} 2)$, 8.1-7.9 (2H, m, Ar-H6, Ar-H3), $4.99\left(2 \mathrm{H}, \mathrm{s}, \mathrm{CH}_{2}\right), 3.80\left(3 \mathrm{H}, \mathrm{s}, \mathrm{OCH}_{3}\right) ; \delta_{\mathrm{c}}\left(100 \mathrm{MHz}, \mathrm{CDCl}_{3}\right)$, $168.4,163.4,139.6,133.7,132.4,131.6,131.5,131.2,131.1,129.4,129.3,128.1,127.9,127.4$, 122.6, 121.1, 52.5, 41.3; m/z: $327.2(\mathrm{M}+\mathrm{Na})^{+}, 329.2630 .5(2 \mathrm{M}+\mathrm{Na})^{+} ; v_{\max }(\mathrm{KBr}) / \mathrm{cm}^{-1} 1753$, 1702, 1661. 1589, 1216, 1178.

\section{General synthesis of 1 and 2 and related compounds}

The 4-chloro-1,8-naphthalimide derivative (1 eq.) was suspended in excess amine. The resulting solution was heated to $80^{\circ} \mathrm{C}$ for $12 \mathrm{~h}$. The product was precipitated out by pouring the resulting mixture onto an iced water solution with vigorous stirring. The product was filtered off and washed with $1 \mathrm{~N} \mathrm{HCl}$ solution. No further purification was necessary.

\section{$N$-[1-(2-Piperidino-ethyl)-carboxamido-methyl]-4-(2-piperidino-ethylamino-1,8-naphthal-}

imide (1) was synthesised by refluxing $N$-(1-methoxycarbonyl-methyl)-4-chloro-1,8-naphthalimide, $3(0.5 \mathrm{~g}, 1.6 \mathrm{mmol})$ in 4-(2-amino ethyl)-piperidine $(2 \mathrm{ml})$ according to above procedure. The product was isolated after recrystallisation from $\mathrm{EtOH}$ as a bright orange powder $(0.55 \mathrm{~g}$, $74.3 \%$ yield). m. p. $135-136^{\circ} \mathrm{C} ; \mathrm{m} / \mathrm{z}$ : $492.2971\left([\mathrm{M}+\mathrm{H}]^{+} \mathrm{C}_{28} \mathrm{H}_{38} \mathrm{~N}_{5} \mathrm{O}_{3}\right.$ requires 492.2975); $\delta_{\mathrm{H}}$ 


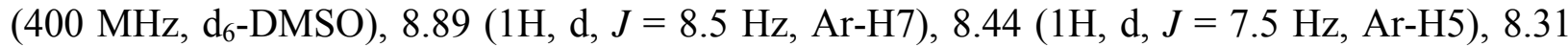
$(1 \mathrm{H}, \mathrm{d}, J=8.5 \mathrm{~Hz}, \mathrm{Ar}-\mathrm{H} 2), 7.99(1 \mathrm{H}, \mathrm{t}, J=5.5 \mathrm{~Hz}, \mathrm{NH}), 7.67(1 \mathrm{H}, \mathrm{dd}, J=7.5,8.0 \mathrm{~Hz}, \mathrm{Ar}-\mathrm{H} 6)$, $7.62(1 \mathrm{H}, \mathrm{t}, J=5.5 \mathrm{~Hz}, \mathrm{NH}), 6.78(1 \mathrm{H}, \mathrm{d}, J=8.5 \mathrm{~Hz}, \mathrm{Ar}-\mathrm{H} 3), 4.62\left(2 \mathrm{H}, \mathrm{s}, \mathrm{CH}_{2} \mathrm{CO}\right), 3.51(2 \mathrm{H}, \mathrm{q}$, $\left.J=6.5,6.0 \mathrm{~Hz}, \mathrm{CH}_{2}\right), 3.31\left(2 \mathrm{H}, \mathrm{q}, J=7.0,6.0 \mathrm{~Hz}, \mathrm{CH}_{2}\right), 2.58\left(10 \mathrm{H}, \mathrm{m},\left(\mathrm{CH}_{2}\right) \times 5\right), 1.45-140$ $\left(14 \mathrm{H}, \mathrm{m},\left(\mathrm{CH}_{2}\right) \times \mathrm{7}\right) ; \delta_{\mathrm{c}}\left(100 \mathrm{MHz}, \mathrm{d}_{6}-\mathrm{DMSO}\right), 166.8,163.6,162.7,150.6,134.2,130.6,129.5$, 128.4, 124.2, 121.8, 120.1, 107.5, 103.8, 57.5, 56.4, 54.1, 54.0, 41.9, 40.5, 36.3, 25.5, 25.4, 23.9; $v_{\max }(\mathrm{KBr}) / \mathrm{cm}^{-1} 3396,3381,3300,2937,1693,1653,1589,1397,1106$.

\section{$\mathrm{N}$-[1-(2-morpholino-ethyl)-carboxamido-methyl]-4-(2-morpholino-ethylamino)-1,8-naph-}

thalimide (2) was synthesised by refluxing $N$-(1-methoxycarbonyl-methyl)-4-chloro-1,8naphthalimide, $3(0.5 \mathrm{~g}, 1.6 \mathrm{mmol})$ in 4-(2-amino ethyl)-morpholine $(2 \mathrm{ml})$ according to above procedure. The product was isolated after recrystallisation from DMF as a bright orange powder (0.62 g, $80 \%$ yield). m. p. $242-243^{\circ}$ C. Found: C, 62.80; H, 6.69; N, $14.09 \%$. $\mathrm{C}_{26} \mathrm{H}_{35} \mathrm{~N}_{5} \mathrm{O}_{5}$ requires $\mathrm{C}, 62.76 ; \mathrm{H}, 7.12 ; \mathrm{N}, 14.07 \%$; $\delta_{\mathrm{H}}\left(400 \mathrm{MHz}, \mathrm{CDCl}_{3}\right), 8.51(1 \mathrm{H}, \mathrm{d}, J=7.5 \mathrm{~Hz}, \mathrm{Ar}-\mathrm{H} 7)$, $8.44(1 \mathrm{H}, \mathrm{d}, J=8.5 \mathrm{~Hz}, \mathrm{Ar}-\mathrm{H} 5), 8.10(1 \mathrm{H}, \mathrm{d}, J=8.5 \mathrm{~Hz}, \mathrm{Ar}-\mathrm{H} 2), 7.62(1 \mathrm{H}, \mathrm{dd}, J=8.0,7.5 \mathrm{~Hz}$, Ar-H6), $6.56(1 \mathrm{H}, \mathrm{d}, J=8.0 \mathrm{~Hz}, \mathrm{Ar}-\mathrm{H} 3), 6.45\left(2 \mathrm{H}\right.$, br s, NH), $4.92\left(2 \mathrm{H}, \mathrm{s}, \mathrm{NCH}_{2}\right), 3.78(4 \mathrm{H}, \mathrm{s}$, $\left.\mathrm{N}\left(\mathrm{CH}_{2} \underline{\mathrm{CH}}_{2}\right)_{2} \mathrm{O}\right), 3.50\left(4 \mathrm{H}, \mathrm{s}, \mathrm{N}\left(\mathrm{CH}_{2} \underline{\mathrm{CH}}_{2}\right)_{2} \mathrm{O}\right), 3.46-3.43\left(4 \mathrm{H}\right.$, br m, $\left.\mathrm{NHCH}_{2}\right), 2.81(2 \mathrm{H}, \mathrm{t}, J=5.5$ $\left.\mathrm{Hz}, \mathrm{CH}_{2} \mathrm{~N}\right), 2.56\left(4 \mathrm{H}\right.$, br s, $\left.\mathrm{N}\left(\underline{\mathrm{CH}}_{2} \mathrm{CH}_{2}\right)_{2} \mathrm{O}\right), \delta 2.50\left(2 \mathrm{H}, \mathrm{t}, J=5.5 \mathrm{~Hz}, \mathrm{CH}_{2} \mathrm{~N}\right), 2.43(4 \mathrm{H}$, br s, $\left.\mathrm{N}\left(\underline{\mathrm{CH}}_{2} \mathrm{CH}_{2}\right)_{2} \mathrm{O}\right) ; \delta_{\mathrm{c}}\left(100 \mathrm{MHz}, \mathrm{CDCl}_{3}\right), 167.2,164.0,163.2,149.5,139.2,137.6,134.4,131.0$, $129.4,126.2$, 124.3, 121.9, 119.9, 108.9, 104.0, 66.6, 66.3, 56.2, 55.6, 52.8, 52.7, 42.6, 38.7, $35.2 ; \mathrm{m} / \mathrm{z}: 495.8(\mathrm{M})^{+}, 517.8(\mathrm{M}+\mathrm{Na})^{+} ; v_{\max }(\mathrm{KBr}) / \mathrm{cm}^{-1} 3374,3300,2942,2825,1691,1652$, $1588,1397,1109$.

N-[1-(2-Butyl)-carboxamido-methyl]-4-(1-butylamino)-1,8-naphthalimide (5) was synthesised by refluxing $N$-(1-methoxycarbonyl-methyl)-4-chloro-1,8-naphthalimide, 3 (0.3 g, 0.94 mmol) in $n$-butylamine $(3 \mathrm{ml})$ according to the above procedure. The product was isolated after recrystallisation with $\mathrm{DMF} /$ water as a bright orange powder $(0.25 \mathrm{~g}, 69.4 \%$ yield $)$. m. p. 239 $240^{\circ} \mathrm{C}$. Found: $\mathrm{C}, 68.54 ; \mathrm{H}, 7.08 ; \mathrm{N}, 10.87 \% . \mathrm{C}_{22} \mathrm{H}_{27} \mathrm{~N}_{3} \mathrm{O}_{3}$ with $0.67 \mathrm{H}_{2} \mathrm{O}$ requires $\mathrm{C}, 68.46$; $\mathrm{H}$, 7.18; N, $10.89 \%$; $\delta_{\mathrm{H}}\left(400 \mathrm{MHz}, \mathrm{d}_{6}\right.$-DMSO), $8.78(1 \mathrm{H}, \mathrm{d}, J=8.5 \mathrm{~Hz}, \mathrm{Ar}-\mathrm{H} 7), 8.44(1 \mathrm{H}, \mathrm{d}, J=$ $7.5 \mathrm{~Hz}, \mathrm{Ar}-\mathrm{H} 5), 8.32(1 \mathrm{H}, \mathrm{d}, J=8.5 \mathrm{~Hz}, \mathrm{Ar}-\mathrm{H} 2), 8.01(1 \mathrm{H}$, br s, NH), $7.81(1 \mathrm{H}$, br s, NH), 7.67 $(1 \mathrm{H}, \mathrm{t}, J=8.0 \mathrm{~Hz}, \mathrm{Ar}-\mathrm{H} 5), 6.83(1 \mathrm{H}, \mathrm{d}, J=9.0 \mathrm{~Hz}, \mathrm{Ar}-\mathrm{H} 3), 4.56\left(1 \mathrm{H}, \mathrm{s}, \mathrm{CH}_{2} \mathrm{CO}\right), 3.42$ (2H, q, J $\left.=7.0,6.0 \mathrm{~Hz}, \mathrm{CONHCH}_{2}\right), 3.10\left(2 \mathrm{H}, \mathrm{q}, J=7.0,6.0 \mathrm{~Hz}, \mathrm{NHCH}_{2}\right), 1.67(2 \mathrm{H}$, quin, $J=7.0,7.5$ $\left.\mathrm{Hz}, \mathrm{CONHCH}_{2} \underline{\mathrm{CH}}_{2}\right), 1.51\left(4 \mathrm{H}, \mathrm{m}, \mathrm{CONH}\left(\mathrm{CH}_{2}\right)_{2} \underline{\mathrm{CH}}_{2}\right.$ and $\left.\mathrm{NHCH}_{2} \underline{\mathrm{CH}}_{2}\right), 1.33(2 \mathrm{H}$, sextet, $J=$ 7.0, 7.5, 7.0 Hz, NH(CH$\left.)_{2} \underline{\mathrm{CH}}_{2}\right), 1.03\left(3 \mathrm{H}, \mathrm{t}, J=7.0 \mathrm{~Hz}, \mathrm{CONH}\left(\mathrm{CH}_{2}\right)_{3} \underline{\mathrm{CH}}_{3}\right), 0.89(3 \mathrm{H}, \mathrm{t}, J=7.0$ $\left.\mathrm{Hz}, \mathrm{NH}\left(\mathrm{CH}_{2}\right)_{3} \mathrm{CH}_{3}\right) ; \delta_{\mathrm{c}}\left(100 \mathrm{MHz}, \mathrm{d}_{6}\right.$-DMSO), 166.7, 163.6, 162.7, 150.7, 134.2, 130.6, 129.6, 128.6, 124.1, 121.8, 120.1, 107.4, 103.7, 42.5, 41.9, 38.2, 31.1, 29.9, 19.7, 19.4, 13.7, 13.6; m/z: $382.1(\mathrm{M})^{+}, 309.0\left(\mathrm{M}-\mathrm{NH}\left(\mathrm{CH}_{2}\right)_{3} \mathrm{CH}_{3}\right)^{+} ; v_{\max }(\mathrm{KBr}) / \mathrm{cm}^{-1} 3443,3316,2955,1690,1664,1629$, $1583,1534,1377$. 


\section{Acknowledgements}

We thank Trinity College Dublin and Queen's University Belfast, National Pharmaceutical Biotechnology Centre, BioResearch Ireland, Centre for Synthesis and Chemical Biology, Kinerton Ltd and The Royal Society (for a University Research Fellowship to CPMcC) for financial support, Drs. Hazel M. Moncrieff and Frederick M. Pfeffer for helpful discussion and Dr. John E. O'Brien for assisting with NMR. We would particularly like to thank Professor A. P. de Silva, Queen's University of Belfast, and Dr. H. Q. Nimal Gunaratne, QUILL (Queen's University Ionic Liquid Laboratories), for their continuous support and friendship over the years.

\section{References and Notes}

$\S$ Parts of this work have been submitted as a communication.

1. (a) Rurack, K.; Resch-Genger, U.; Chem. Soc. Rev. 2002, 116. (b) Lavigne J.J.; Anslyn E. V. Angew. Chem. Int. Ed. 2001, 40, 3119. (c) Amendola, V.; Fabbrizzi, L.; Mangano, C.; Pallavicini, P. Acc. Chem. Res. 2001, 34, 488. (d) de Silva, A. P.; Fox, D. B.; Huxley, A. J. M.; Moody, T. S. Coord. Chem. Rev. 2000, 205, 41.

2. (a) Fabbrizzi, L.; Licchelli, M.; Pallavicini, P. Acc. Chem. Res. 1999, 32, 846. (b) Czarnik, A.W. Acc. Chem. Res. 1994, 27, 302. (b) Raymo, F. M., Adv. Mater. 2002, 14, 401. (c) Raymo, F. M.; Giordani, S. J. Am. Chem. Soc. 2002, 124, 2004. (d) Raymo, F. M.; Giordani, S. J. Am. Chem. Soc. 2001, 123, 4651. (e) Balzani, V.; Credi, A.; Raymo, F. M.; Stoddart, J. F., Angew. Chem. Int. Ed. 2000, 39, 3348.

3. (a) Atwood, J. L.; Davies, J. E. D.; Macnicol D. D. Comprehensive Supramolecular Chemistry, Vögtle, F. Ed; Pergamon: England, 1996; Vol. 1, 2 and 10 (b) Molecular Electronics and Molecular Electronic Devices, Sienicki, K. Ed.; CRC Press: USA, 1993; Vol. 1-2. (c) Balzani V.; Scandola, F. Supramolecular Photochemistry, Ellis Horwood: Chichster, 1991.

4. (a) de Silva, A. P.; Gunaratne, H. Q. N.; Gunnlaugsson, T.; Huxley, A. J. M.; McCoy, C. P.; Rademacher J. T.; Rice, T. E. Chem. Rev. 1997, 97, 1515. (b) Fabbrizzi, L.; Licchelli, M.; Pallavicini, P. Acc. Chem. Res. 1999, 32. 846. (c) Licini, M.; Williams; J. A. G. Chem. Commun. 1999, 1943.

5. He, H.; Mortellaro, M. A.; Leiner, M. J. P.; Young, S. T.; Fraatz, R. J.; Tusa, J. K. Anal. Chem. 2003, 75, 549, and references therein.

6. (a) Gunnlaugsson, T.; Nieuwnhuyzen, M.; Richard, L.; Thoss, V. J. Chem. Soc. Peerkin 2, 2002, 141. (b) Gunnlaugsson T.; Bichell B.; Nolan C. Tetrahedron Lett. 2002, 43, 4989.

7. Bissell, R.A.; de Silva, A.P.; Gunaratne, H.Q.N.; Lynch, P.L.M.; Maguire, G.E.M.; McCoy C.P.; Sandanayake, K.R.A.S. Top. Curr. Chem. 1993, 168, 223. 
8. (a) de Silva, A. P.; Fox. D. B.; Huxley, A. J. M.; McClenaghan, N. D.; Roiron, J. Coord. Chem. Rev. 1999, 186, 297. (b) de Silva, A. P.; Gunaratne, H. Q. N.; Gunnlaugsson, T.; Huxley, A. J .M.; McCoy, C. P.; Rademacher J. T.; Rice, T. E. Chem. Rev. 1997, 97, 1515.

9. (a) Gunnlaugsson, T.; Davis, A. P.; O’Brien, J.E.; Glynn, M. Organic Lett. 2002, 4, 2449.

(b) Gunnlaugsson T.; Davis, A. P.; Glynn, M., Chem. Commun., 2001, 2556.

10. (a) Gunnlaugsson T.; Leonard J. Chem. Soc. Perkin 2 2002, 1980. (b) Gunnlaugsson, T.; Nieuwnhuyzen, M.; Richard, L.; Thoss, V. Tetrahedron Lett. 2001, 42, 4725.

11. (a) Gunnlaugsson, T.; Harte, A. J.; Leonard, J. P.; Nieuwenhuyzen, M. Supramol. Chem. 2003, 13, in press. (b) Gunnlaugsson, T.; Harte, A. J.; Leonard, J. P.; Nieuwenhuyzen, M. Chem. Commun. 2002, 2134. (c) Gunnlaugsson, T.; Mac Dónaill, D. A.; Parker, D. J. Am. Chem. Soc. 2001, 123, 12866. (d) Gunnlaugsson, T. Mac Dónaill D. A.; Parker, D. Chem. Commun. 2000, 93. (e) Gunnlaugsson, T.; Parker, D. Chem. Commun. 1998, 511.

12. (a) de Silva, A. P.; Gunaratne H.Q. N.; Lynch, P. L. M. New. J. Chem. 1996, 20, 871. (b) de Silva, A. P.; Gunaratne H.Q. N.; Rice, T. E. Angew. Chem. Int. Ed. Engl. 1996, 35, 2116.

13. (a) de Silva, A.P.; Rice, T.E. Chem. Commun., 1999, 163. (b) de Silva, A. P.; Gunaratne, H.Q.N.; Gunnlaugsson, T. Tetrahedron Lett. 1998, 39, 5077.

14. He, H.; Mortellaro, M. A.; Leiner, M. J. P.; Young, S. T.; Fraatz, R. J.; Tusa, J. K. J. Am. Chem. Soc. 2003, 125, 1468.

15. Recently, both Grabchev et. al. and Tian et. al. have developed polymers by incorporating 1,8-naphthalimide units covalently into the polymer backbone: (a) Grabchev, I.; Qian, X.; Xiao, Y.; Zhang, R. New. J. Chem. 2002, 26, 920. (b) Bojinov V.; Grabchev, I. Dyes and Pigments 2001, 51, 57. (c) Grabchev, I.; Bojinov, V.; Petkov, C. Dyes and Pigments 2001, 51, 1. (d) Grabchev, I. Dyes and Pigments 1998, 38, 219. (e) Tian, H.; Gan, J.; Chen, K.; He, K.; He, J.; Song, Q. L.; Hou, X. Y. J. Mart. Chem. 2002, 12, 1262. Synthetic Metals 2000, $111,477$.

16. de Silva, A. P.; Gunaratne H. Q. N.; McCoy, C. P. Nature 1993, 364, 42.

17. Lydon, M. J.; Minett, T. J.; Tighe, B. J. Biomaterials 1985, 6, 396.

18. (a) Wichterle, O.; Lim, D. Nature 1960, 185, 117. (b) Mack, E. J.; Okano, T.; Kim, S. W In Peppas, N. A. Ed. Hydrogels in Medicine and Pharmacy, Volume 2: Polymers, CRC Press: Boca Raton, 2000, 65.

(b) Peppas, N. A.; Bures, P.; Leobandung, W.; Ichikawa, H. Eur. J. Pharm. Biopharm. 2000, 50, 27.

19. (a) Rosiak, J. M.; Ulański, P.; Rzeźnicki, A. Nucl. Instr. and Meth. in Phys. Res. B 1995, 105, 335. (b) Rosiak, J. M.; Yoshii, F. Nucl. Instr. and Meth. in Phys. Res. B 1999, 151, 56.

20. Bissell, R.A.; de Silva, A.P.; Gunaratne, H.Q.N.; Lynch, P.L.M.; Maguire, G.E.M.; Sandanayake, K.R.A.S. Chem. Soc. Rev. 1992, 21,187.

21. de Silva, A. P.; Gunaratne, H.Q.N.; Habib-Jiwan, J.-L.; McCoy, C.P.; Rice, T.E.; Soumillion, J.-P. Angew. Chem. Int. Ed. Engl. 1995, 34, 1728.

22. (a) Paddock, S. W. Biotechniques 1999, 27, 992. (b) Wright, S. J.; Wright, D. J. Methods in Cell Biol. 2002, 70, 1. (b) Hanthamrongwit, M.; Wilkinson, R.; Osborne, C.; Reid, W. H.; Grant, M. H. J. Biomed. Mater. Res. 1996, 30, 331.

23. Paddock, S. W. Mol. Biotechnol. 2000, 16, 127. 